\title{
STUDI PENGEMBANGAN PERPARKIRAN KOTA BAUBAU
}

\author{
Muhammad Yusri Lukman ${ }^{1}$ Andi Muhammad Ikhsan ${ }^{2}$ Muhammad Zaki ${ }^{3}$ \\ 1,2,3 Program Studi Arsitektur Universitas Muslim Indonesia
}

\begin{abstract}
ABSTRAK
Meningkatnya pembangunan disetiap kota kususnya pusat-pusat bisnis ternyata belum mampu menyediakan lahan parkir yang mencukupi, sehingga badan jalan yang berada di sekitarnya digunakan untuk lahan parkir. Apabila badan jalan tersebut dilalui lalu lintas dalam jumlah yang cukup besar maka bisa dipastikan bahwa parkir di badan jalan akan menimbulkan permasalahan lalu lintas (kecepatan menurun dan waktu tempuh meningkat. Timbulnya permasalahan parkir di kota-kota besar mengajak masyarakat dan para akhli untuk berfikir dan betul-betul memahami sistem perparkiran. Konsep dan karakteristik parkir, analisis kebutuhan parkir, perencanaan geometrik lahan parkir, serta kebijakan parkir merupakan salah satu ide yang bias diimplementasikan untuk menangani permasalahan parkir khususnya di Kota Baubau. Penelitian ini bertujuan 1.Mengkaji kelayakan lokasi perparkiran yang terbaik, optimal dan mempunyai prospek yang baik bagi pengembangan wilayah Kota Baubau; 2.Mengkaji kelayakan sosial budaya masyarakat kaitannya dengan rencana Penentuan lokasi-lokasi perparkiran, baik skala mikro (kelayakan sosial budaya pada lokasi terpilih) maupun skala makro (kelayakan sosial budaya dikaitkan dengan Kota Baubau secara keseluruhan); 3.Mengkaji kelayakan lingkungan pada titik-titik lokasi perparkiran agar tidak terjadi degradasi lingkungan akibat adanya perencanaan lokasi parkir; 4. Mengkaji aspek ekonomi dan memperhitungkan tingkat pendapatan pada saat pengoperasian sistem perparkiran berjalan, perkiraan biaya investasi yang dibutuhkan untuk pembangunan area perparkiran serta memperkirakan pengembalian investasi dengan asumsi-asumsi yang rasional dan realistis. Metode Pengumpulan data dilakukan dengan dua cara yakni survey sekunder dan survey primer,
\end{abstract}

Kata kunci : Pengembangan, perparkiran, kota

\section{PENDAHUUAN}

Dalam kehidupan sehari-hari parkir sudah menjadi pemandangan yang khas disetiap aktifitas masyarakat kota. Daerah perkotaan dengan kepadatan penduduk dan tingkat ekonomi yang tinggi mengakibatkan tingkat kepemilikan kendaraan pribadi yang tinggi pula. Apabila kondisi ini didukung dengan kebijakan pemerintah dalam manajemen lalu lintas yang tidak membatasi penggunaan mobil pribadi, maka akan mendukung pelaku pergerakan untuk selalu menggunakan kendaraan pribadi. Timbulnya permasalahan parkir di kota-kota besar mengajak masyarakat dan para akhli untuk berfikir dan betul-betul memahami sistem perparkiran.

Konsep dan karakteristik parkir, analisis kebutuhan parkir, perencanaan geometrik lahan parkir, serta kebijakan parkir merupakan salah satu ide yang bias diimplementasikan untuk menangani permasalahan parkir khususnya di Kota Baubau. Saat ini perparkiran menjadi salah satu fenomena yang mempengaruhi pergerakan kendaraan disaat kendaraan-kendaraan yang mempunyai intensitas pergerakan yang begitu tinggi akan terhambat oleh kendaraan yang parkir di bahu jalan sehingga menyebabkan kemacetan. Pada umumnya kendaraan yang parkir di pinggir jalan berada di sekitar tempat atau pusat kegiatan seperti : sekolah, kantor, pasar swalayan, pasar tradisional, rumah makan, dan lainlain. Salah satu usaha yang perlu dilakukan untuk menangani masalah perparkiran tersebut, diperlukan pengadaan lahan parkir yang cukup memadai dan pembentukan model lahan parkir yang tepat pada lahan parkir yang tersedia, mengingat kebutuhan akan lahan parkir (demand) dan prasarana yang dibutuhkan (supply) harus seimbang dengan karakteristik perparkiran. Parkir semestinya hanya digunakan untuk memberhentikan kendaraan untuk sementara, tidak dalam waktu lama atau bahkan berhari-hari yang dilakukan. Penggunaan parkir sesuai peraturan yang rapi akan memudahkan petugas parkir dalam memarkirkan kendaraan.

Dapat digaris bawahi bahwa kegiatan parkir seharusnya tidak mengganggu pergerakan ruang lalu lintas dan juga tidak mengganggu pejalan kaki, tapi pada kenyataannya kegiatan perparkiran yang selama ini berlangsung terutama on street parking sering menghambat pergerakan lalu lintas, sehingga muncullah permasalahan kemacetan. Hal ini dikarenakan penggunaan lahan parkir yang tidak seharusnya. Misalnya adalah pemakaian lahan parkir yang tidak seharusnya oleh pengguna kendaraan yang tidak memarkirkan kendaraannya dengan benar, kendaraan tidak diparkirkan sesuai dengan posisi parkir yang sudah ditandai dengan marka parkir. Banyaknya masyarakat yang lebih memilih on street parking dibandingkan dengan off street parking dikarenakan on street parking lebih mudah dan lebih cepat untuk dilakukan. Selain dekat dengan tempat yang akan di kunjungi on street 
parking juga dapat diawasi secara jelas oleh penjaga parkir, karena rata-rata penjaga parkir menjaga sekitar 10 kendaraan selama bertugas. Sedangkan sistem metode off street parking mengharuskan pengemudi mencari tempat berkeliling gedung sebelum memarkirkan kendaraan mereka karena kebanyakan parkir di dalam gedung memiliki lahan yang luas. Namun demikian, penggunaan on street parking juga memiliki kekurangan bagi kelancaran lalu lintas di sekitarnya. Karena lahan parkir di badan jalan tidak begitu luas dibandingkan system perparkiran di dalam gedung.

Kapasitas parkir yang sesuai dan letak parkir yang digunakan dengan baik dan benar tentu tidak akan mengakibatkan penghambatan lalu lintas. Posisi dan letak parkir sudah ditentukan oleh Pemerintah Daerah, seharusnya ketika pengguna kendaraan memarkirkan kendaraannya harus diperhatikan ketepatannya dalam memposisikan letak parkir kendaraannya. Namun kenyataannya penggunaan lahan parkir sering tidak dipatuhi baik oleh pengguna maupun pengelola parkir.

\section{ISI PENELITIAN}

\subsection{Metode}

Jenis penelitian yang digunakan adalah penelitian deskriptif dengan pendekatan kualitatif. Jenis data terbagi menjadi dua yaitu data primer dan sekunder. Data primer diperoleh secara langsung dengan melakukan observasi di lapangan serta wawancara langsung yang berhubungan dengan data-data yang dibutuhkan berupa data tentang banjir, guna lahan dan lain sebagainya. Data Sekunder, diperoleh dari kantor instansi terkait (dokumentasi) yang mengetahui fisik lingkungan berupa topografi kawasan, serta referensi-referensi lainya yang relevan dengan masalah pokok dalam penelitian ini.

\subsection{Gambaran Umum Kota Baubau}

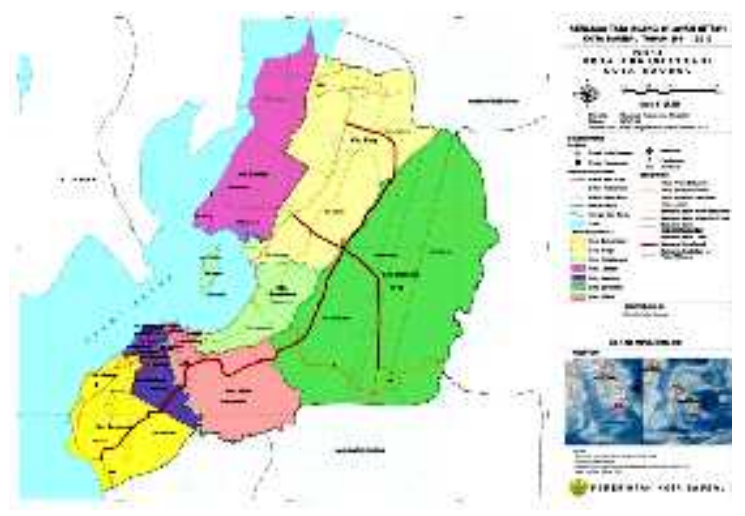

Gambar 1. Peta Administrasi Kota Baubau

Sumber : RTRW Kota Baubau 2011-2030

Secara geografis Kota Baubau terletak di bagian Selatan Provinsi Sulawesi Tenggara yang berupa wilayah kepulauan. Kota Baubau berada di Pulau Buton dengan posisi koordinat sekitar $0,5^{\circ} 15^{\prime}$ hingga $0,5^{\circ} 32^{\prime}$ Lintang Selatan dan $1220^{\circ} 46^{\prime}$ Bujur Timur. Dengan posisi tersebut, secara geostrategic kota Baubau berperan sebagai kota transit sekaligus daerah penghubung ( Connecting area ) antara Kawasan Barat Indonesia (KBI) dengan Kawasan Timur Indonesia (KTI).

Secara fisik, Kota Baubau terletak pada Selat Buton dan dikelilingi oleh kecamatan-kecamatan dari Kabupaten Buton. Menurut Undang-Undang Nomor 13 Tahun 2001, batas-batas administrasi Kota Baubau adalah sebagai berikut:

- Sebelah Utara berbatasan dengan Kecamatan Kapontori Kabupaten Buton;

- Sebelah Timur berbatasan dengan Kecamatan Pasarwajo Kabupaten Buton;

- Sebelah Selatan berbatasan dengan Kecamatan Batauga Kabupaten Buton;

- Sebelah Barat berbatasan dengan Selat Buton. Luas wilayah Kota Baubau menurut BPS adalah sekitar 221,00 km 2 atau $0,58 \%$ luas daratan Provinsi Sulawesi Tenggara. Akan tetapi, berdasarkan hasil perhitungan foto udara, luas wilayah Kota Baubau adalah 29,02 km 2

\section{HASIL DAN PEMBAHASAN}

\subsection{Data dan Analisis Perkembangan Tata Guna Lahan}

Secara garis besar penggunaan lahan di Kota Baubau dapat dibedakan atas penggunaan lahan perkotaan (urban) dan penggunaan lahan non urban (rural). Jenis penggunaan lahan yang dikategorikan urban, meliputi; perumahan, industri, pergudangan, sosial dan jasa, perdagangan. Sedangkan untuk lahan non urban meliputi sawah, tambak, kebun campuran, padang rumput, semak, dan hutan. Penggunaan lahan perkotaan (urban) cenderungan berada di kota bawah di sekitar pantai, sedang untuk kota atas kegiataan pertanian masih mendominasi penggunaan lahan pada daerah tersebut.

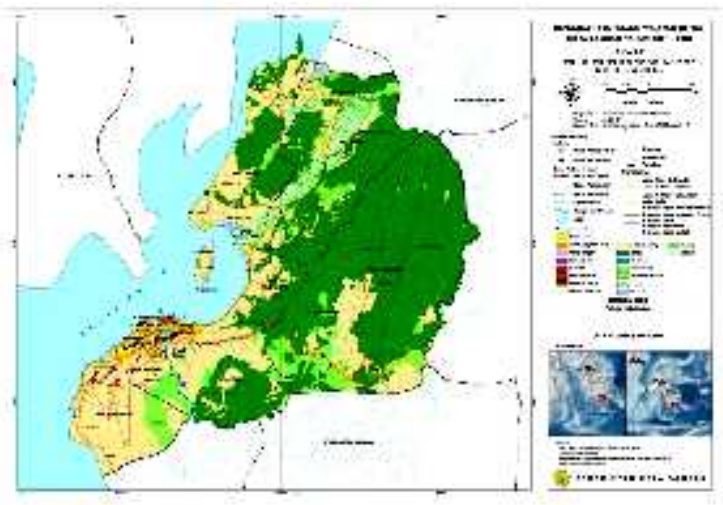

Gambar 2. Peta Administrasi Kota Baubau Sumber : RTRW Kota Baubau 2011-2030

Rasio luas areal terbangun Kota Baubau relatif masih rendah yaitu sebesar $2.028 \mathrm{Ha}$ atau 9,18\% dari luas total wilayah kota. Secara umum kawasan terbangun didominasi oleh bangunan perumahan, fasilitas sosial, jasa, perdagangan, industri dan jaringan infrastruktur. Sedangkan kawasan yang 
belum terbangun mempunyai luas $20.072 \mathrm{Ha}$ atau $90,82 \%$ dari luas total wilayah Kota Baubau. Kawasan yang belum terbangun ini didominasi oleh pemanfaatan hutan dengan luas $9.543 \mathrm{Ha}$ atau $43,18 \%$ dari total luas lahan. Pemanfaatan lahan lainnya yaitu digunakan sebagai tegal/kebun yaitu sebesar 13,28\% atau seluas $2.934 \mathrm{Ha}$, sisanya berturut-turut adalah perkebunan $1.901 \mathrm{Ha}$ atau $8,60 \%$, ladang $1.531 \mathrm{Ha}$ atau 6,93\%, lainnya 1.368 Ha atau 6,19\%

\subsection{Indeks Parkir dan Tingkat Kejenuhan}

Indeks Parkir dihitung menggunakan persamaan dibawah ini :

\begin{tabular}{cl} 
& \multicolumn{1}{c}{$\mathrm{IP}=R / A P \times 100 \%$} \\
Dimana : & $\mathrm{IP}=$ Indeks Parkir \\
& $\mathrm{AP}=$ Akumulasi Parkir \\
$\mathrm{R}=$ Ruang Parkir yang tersedia
\end{tabular}

Tabel 1. Indeks Parkir Berdasarkan Lokasi Parkir

\begin{tabular}{|c|c|c|}
\hline lokasi kegiatan & normal & $\begin{array}{c}\text { tidak } \\
\text { normal }\end{array}$ \\
\hline \multicolumn{3}{|l|}{ LOKASI I } \\
\hline $\begin{array}{l}\text { - J1. R.A. Kartini } \\
\text { (Samping Kanan } \\
\text { Masjid Raya - } \\
\text { Depan Kantor } \\
\text { SatPol-PP) }\end{array}$ & 8 & 4 \\
\hline $\begin{array}{l}\text { - Jl. Jend. } \\
\text { Sudirman } \\
\text { (Samping Kiri } \\
\text { Masjid Raya - } \\
\text { Depan Kantor } \\
\text { SatPol-PP) }\end{array}$ & 7 & 2 \\
\hline $\begin{array}{l}\text { - Depan } \\
\text { Pasar/Pertokoan }\end{array}$ & 6 & 0 \\
\hline $\begin{array}{l}\text { - Jl. W. Monginsidi } \\
\text { (Depan Masjid } \\
\text { Raya) }\end{array}$ & 9 & 5 \\
\hline \multicolumn{3}{|l|}{ LOKASI II } \\
\hline - Jl. Yos Sudarso & 2 & 1 \\
\hline $\begin{array}{l}\text { - Jl. W. Monginsidi } \\
\text { Pertokoan }\end{array}$ & 12 & 3 \\
\hline - Jl. D.I. Pandjaitan & 6 & 2 \\
\hline $\begin{array}{l}\text { - Jl. R.A. Kartini } \\
\text { RUKO }\end{array}$ & 7 & 4 \\
\hline • Jl. P. Tandean & 6 & 1 \\
\hline \multicolumn{3}{|l|}{ LOKASI III } \\
\hline - PLAZA & 9 & 2 \\
\hline
\end{tabular}

Dari hasil yang didapatkan di atas disimpulkan bahwa jumlah lokasi kegiatan yang memiliki tingkat kejenuhan berdasarkan Indeks Parkir (IP $=1$. Normal, IP $<1$. Tidak Bermasalah, IP $>1$. Bermasalah) yakni pada Lokasi II, Jl. R.A. Kartini RUKO dengan tingkat kejenuhan Normal 7 dan Tidak Normal 4.

\subsection{Durasi parkir berdasarkan lokasi kegiatan}

Adalah informasi yang sangat dibutuhkan untuk mengetahui lama suatu kendaraan parkir.
Informasi ini diketahui dengan cara mengamati waktu kendaraan tersebut masuk dan waktu kendaraan tersebut keluar

Durasi $=$ out - in

Ket : in : waktu saat kendaraan masuk lokasi parkir out : waktu saat kendaraan keluar lokasi parkir Untuk perhitungan akumulasi parker didapatkan data-data sebagai berikut :

Tabel 2 Durasi Parkir Berdasarkan Lokasi Kegiatan

\begin{tabular}{|c|c|c|c|c|}
\hline \multirow[t]{2}{*}{ Lokasi Kegiatan } & \multicolumn{2}{|c|}{$\begin{array}{l}\text { Durasi } \\
\text { Parkir } \\
\text { (Menit) }\end{array}$} & \multicolumn{2}{|c|}{$\begin{array}{l}\text { Rata-Rata } \\
\text { Durasi } \\
\text { Parkir } \\
\text { (Menit) }\end{array}$} \\
\hline & $\begin{array}{c}\mathbf{M} \\
\text { ob } \\
\text { il }\end{array}$ & $\begin{array}{c}\mathrm{M} \\
\text { oto } \\
\mathbf{r}\end{array}$ & $\begin{array}{c}\text { Mob } \\
\text { il }\end{array}$ & $\begin{array}{c}\text { Mot } \\
\text { or }\end{array}$ \\
\hline \multicolumn{5}{|l|}{ LOKASI I } \\
\hline $\begin{array}{ll}\text { Jl. R.A. } & \text { Kartini } \\
\text { (Samping } & \text { Kanan } \\
\text { Masjid Raya } & - \text { Depan } \\
\text { Kantor SatPol-PP) }\end{array}$ & $\begin{array}{l}29 . \\
67\end{array}$ & 24 & 4.23 & 3.42 \\
\hline $\begin{array}{lr}\text { Jl. Jend. } & \text { Sudirman } \\
\text { (Samping } & \text { Kanan } \\
\text { Masjid Raya } & - \text { Depan } \\
\text { Kantor SatPol-PP) }\end{array}$ & $\begin{array}{l}47 . \\
67\end{array}$ & $\begin{array}{c}24 . \\
67\end{array}$ & 6.81 & 3.52 \\
\hline $\begin{array}{ll}\text { Jl. Depan } \\
\text { Pasar/Pertokoan }\end{array}$ & 0 & 50 & 0 & 7.14 \\
\hline $\begin{array}{l}\text { Jl. W. Monginsidi } \\
\text { (Depan Masjid Raya) }\end{array}$ & $\begin{array}{l}11 . \\
67 \\
\end{array}$ & $\begin{array}{r}25 . \\
67 \\
\end{array}$ & 1.66 & 3.67 \\
\hline \multicolumn{5}{|l|}{ LOKASI II } \\
\hline Jl. Yos Sudarso & $\begin{array}{l}12 . \\
67\end{array}$ & $\begin{array}{l}24 . \\
33\end{array}$ & 1.81 & 3.47 \\
\hline $\begin{array}{l}\text { Jl. W. Monginsidi } \\
\text { (Pertokoan) }\end{array}$ & $\begin{array}{l}16 . \\
33\end{array}$ & $\begin{array}{c}8.6 \\
7 \\
\end{array}$ & 2.33 & 1.23 \\
\hline J1. D.I. Pandjaitan & 32 & 8 & 4.57 & 1.14 \\
\hline Jl. R.A. Kartini RUKO & $\begin{array}{l}20 . \\
67\end{array}$ & $\begin{array}{c}6.3 \\
3\end{array}$ & 2.95 & 0.90 \\
\hline J1. P. Tandean & $\begin{array}{l}10 . \\
33\end{array}$ & $\begin{array}{c}7.6 \\
7 \\
\end{array}$ & 1.47 & 1.09 \\
\hline \multicolumn{5}{|l|}{ LOKASI III } \\
\hline Plaza & $\begin{array}{l}48 . \\
33\end{array}$ & $\begin{array}{r}43 . \\
67 \\
\end{array}$ & 6.90 & 6.23 \\
\hline
\end{tabular}

Dari hasil yang didapatkan diatas disimpulkan bahwa berdasarkan lokasi kegiatan durasi parkir mobil dan motor memiliki perbedaan yang signifikan. Hal tersebut terbukti bahwa di ketiga lokasi kegiatan penelitian ini memiliki durasi parkir mobil yang cukup lama dibandingkan dengan durasi parkir motor yang agak cukup cepat durasi parkirnya.

3.4. Data Sarana dan Prasarana Transportasi Darat

Faktor utama yang dibutuhkan dalam pergerakan aktivitas wilayah perkotaan adalah ketersediaan sarana dan prasarana transportasi darat. Hal ini disebabkan oleh karena peran dan fungsi transportasi darat yang merupakan titik awal dan 
akhir dari sebuah rangkaian kegiatan transportasi. Apapun transportasi yang digunakan sudah dapat dipastikan akan berawal dan berakhir di darat. Untuk itu keberadaan jaringan jalan di Wilayah Kota Baubau yang merupakan wilayah perkotaan di Pulau Buton akan sangat penting dalam mendistribusikan pergerakan orang, barang dan jasa.

Berdasarkan database Dinas Pekerjaan Umum Kota Baubau, jumlah ruas jalan di Wilayah Kota Baubau sampai dengan saat ini berjumlah 615 ruas jalan. Ruas jalan nasional yang berada dalam wilayah Kota Baubau, yaitu : Jl. R.A. Kartini, Jl. Jenderal Sudirman, Jl. Sultan Hasanuddin, Jl. KS. Tubun, Jl. Anoa, Jl. GajahMada, dan Jl. Murhum. Adapun untuk jaringan jalan provinsi tidak terdapat dalam wilayah Kota baubau, karena seluruh jaringan jalan selain jalan nasional tersebut merupakan jalan kota, dalam sistem jaringan jalan sekunder.

Lebih lanjut, untuk jaringan pelayanan angkutan umum yang ada di wilayah Kota baubau, terdiri atas Taksi, Angkutan Kota, dan Angkutan Kota Dalam Provinsi (AKDP). Jumlah angkutan kota yang beroperasi saat ini adalah 174 kendaraan yang terdiri atas 9 trayek, dengan Terminal Pasar Wameo, dan Terminal Karya Nugraha sebagai pusat pemberangkatan angkutan kota. Namun demikian, walaupun menurut ijin, angkutan tersebut terbagi atas 9 trayek. Tetapi pada kenyataannya secara operasional tidak ditaati. Semua jurusan angkutan dalam kota mempunyai warna yang sama (biru) dan semua jurusan angkutan dalam kota tidak mempunyai keterangan tujuan yang berada di kaca depan maupun dibelakang. Biasanya penumpang sebelum naik angkutan, bertanya dulu kepada supir angkutan kota agar penumpang tidak salah naik angkutan.

Adapun daftar angkutan kota yang beroperasi di Wilayah Perkotaan Baubau, secara lengkap dapat dilihat pada tabel berikut :

Tabel.3 Jumlah Trayek Angkutan Kota di Baubau

\begin{tabular}{|c|c|c|}
\hline 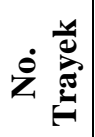 & Jurusan & 莺离 \\
\hline 1 & $\begin{array}{l}\text { Wameo - Melai - Baadai - } \\
\text { Palagimata - (PP) }\end{array}$ & 20 \\
\hline 2 & $\begin{array}{l}\text { Wameo - Waborobo - Palagimata } \\
\text { - (PP) }\end{array}$ & 4 \\
\hline 3 & $\begin{array}{l}\text { Wameo - Kota - Bure - } \\
\text { Betoambari - Palagimata - } \\
\text { Unidayan - (PP) }\end{array}$ & 40 \\
\hline 4 & Kadolokatapi - Wameo - (PP) & 10 \\
\hline 5 & $\begin{array}{l}\text { Lakogou - Perumnas - Wameo - } \\
\text { (PP) }\end{array}$ & 20 \\
\hline 6 & Wameo - Sulaa - (PP) & 15 \\
\hline 7 & $\begin{array}{l}\text { Karya Nugraha - Liabuku - } \\
\text { Lowulowu - Wonco - Kolese - } \\
\text { (PP) }\end{array}$ & 10 \\
\hline 8 & Karya Nugraha - Ngkaring- & 35 \\
\hline
\end{tabular}

\begin{tabular}{|c|l|c|}
\hline & $\begin{array}{l}\text { ngkaring - Wonco - Palabusa - } \\
(\text { PP) }\end{array}$ & 20 \\
\hline 9 & $\begin{array}{l}\text { Karya Nugraha - Karya Baru - } \\
\text { Kaisabu Baru - (PP) }\end{array}$ & 20 \\
\hline
\end{tabular}

Sumber : Dinas Perhubungan Kota Baubau, 2015

Sebagai pusat perkotaan paling besar di Pulau

Buton, Kota Baubau menjadi asal dan tujuan angkutan antar kota dalam provinsi (AKDP) terhadap wilayah kabupaten lain yang ada di Pulau Buton. Berdasarkan data dari Dinas Perhubungan Kota Buton, sesuai dengan perijinan terdapat 227 kendaraan AKDP yang tediri dari 13 trayek AKDP dengan asal tujuan kota Baubau. Kendaraan paling banyak adalah angkuta AKDP jurusan Baubau Masalimu (Kabupaten Buton) dengan jumlah kendaraan sebesar 65 unit, sedangkan yang paling kecil adalah angkutan AKDP jurusan Baubau Barangka (Kabupaten Buton) dengan jumlah kendaraan sebesar 2 unit. Gambaran selengkapnya tentang jumlah angkutan AKDP di Wilayah Kota Baubau, selanjutnya dapat dilihat pada tabel berikut

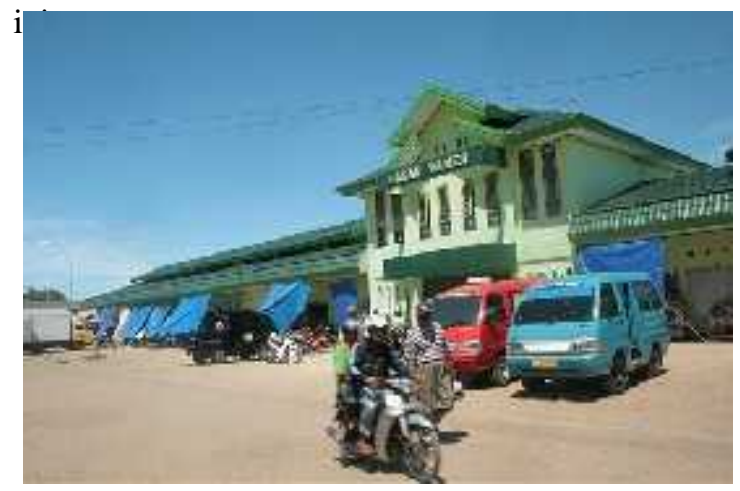

Gambar 3. Terminal Angkutan Umum di Pasar Wameo

Tabel 4. Jumlah Trayek Angkutan AKDP di Baubau

\begin{tabular}{|c|c|c|c|}
\hline No & Jurusan & 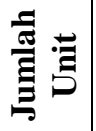 & Daerah \\
\hline 1 & $\begin{array}{l}\text { Baubau - Pasarwajo - } \\
(\mathrm{PP})\end{array}$ & 12 & Kab. Buton \\
\hline 2 & Baubau - Ereke - (PP) & 20 & $\begin{array}{l}\text { Kab. Buton } \\
\text { Utara }\end{array}$ \\
\hline 3 & $\begin{array}{l}\text { Baubau - Lasalimu - } \\
\text { (PP) }\end{array}$ & 65 & Kab. Buton \\
\hline 4 & Baubau - Wabula - (PP) & 12 & Kab. Buton \\
\hline 5 & $\begin{array}{l}\text { Baubau - Batauga - } \\
\text { (PP) }\end{array}$ & 24 & $\begin{array}{l}\text { Kab. Buton } \\
\text { Selatan }\end{array}$ \\
\hline 6 & Baubau - Lande - (PP) & 16 & $\begin{array}{l}\text { Kab. Buton } \\
\text { Selatan }\end{array}$ \\
\hline 7 & $\begin{array}{l}\text { Baubau - Sampolawa - } \\
\text { (PP) }\end{array}$ & 30 & Kab. Buton \\
\hline 8 & $\begin{array}{l}\text { Baubau - Lapandewa - } \\
\text { (PP) }\end{array}$ & 16 & $\begin{array}{l}\text { Kab. Buton } \\
\text { Selatan }\end{array}$ \\
\hline 9 & $\begin{array}{l}\text { Baubau - Barangka - } \\
\text { (PP) }\end{array}$ & 2 & Kab. Buton \\
\hline
\end{tabular}




\begin{tabular}{|c|l|c|c|}
\hline 10 & $\begin{array}{l}\text { Baubau - Kapontori - } \\
(\mathrm{PP})\end{array}$ & 6 & Kab. Buton \\
\hline 11 & Baubau - Kamaru - (PP) & 12 & Kab. Buton \\
\hline 12 & $\begin{array}{l}\text { Baubau - Raha - } \\
\text { Kendari - (PP) }\end{array}$ & 2 & $\begin{array}{c}\text { Kota } \\
\text { Kendari }\end{array}$ \\
\hline 13 & Baubau - Labuan - (PP) & 10 & $\begin{array}{c}\text { Kab. Buton } \\
\text { Utara }\end{array}$ \\
\hline
\end{tabular}

Sumber : Dinas Perhubungan Kota Baubau, 2015

\subsection{DATA DAN ANALISIS KONDISI TAPAK LOKASI PERENCANAAN}

Kawasan perencanaan pembangunan Gedung Parkir berada di kawasan Masjid Agung dan juga Pasar. Penggunaan lahan pada jalur tersebut terdiri campuran beberapa pengguna lahan, akan tetapi lebih didominasi oleh kawasan Perdagangan.

Lokasi Tapak sekitar kawasan terletak di sekitar pasar dan masjid agung. Di sebelah barat tapak, tepat berseberangan dengan jalan trans Sulawesi, terdapat pemukiman penduduk dengan tingkat kepadatan yang masih rendah, walaupun dapat dikatakan kegiatan perekonomian di sekitar tapak tampaknya cukup lancar dan berkembang. Hal ini dikarenakan oleh posisi kawasan yang strategis.

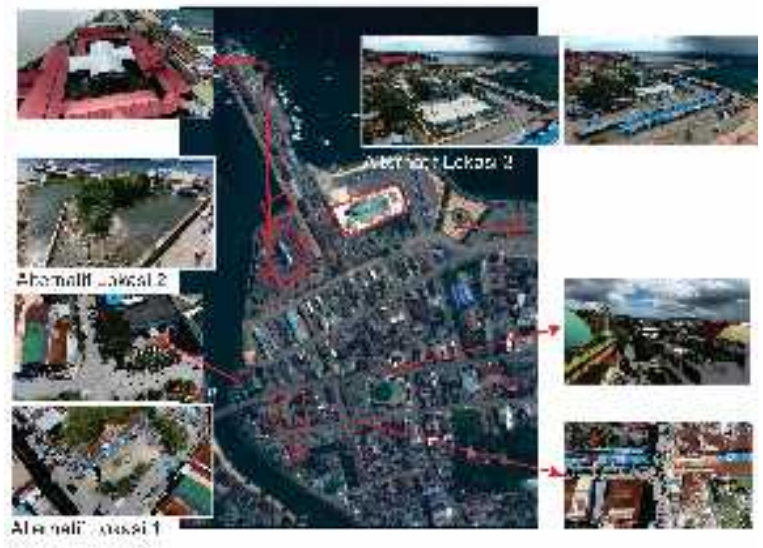

Gambar 3. Kondisi Eksisting Wilayah Studi Sumber : Image Drone

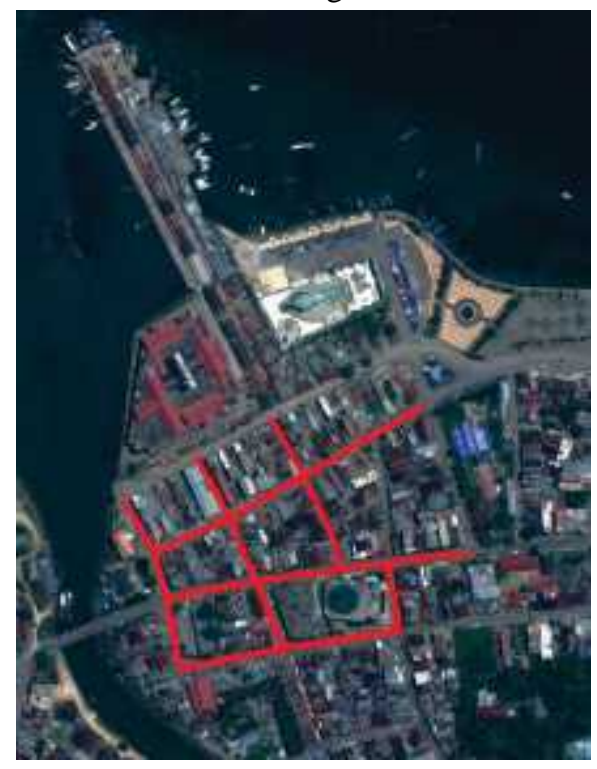

Gambar 3. Kondisi sirkulasi Pergerakan Parkir Sumber : Image Drone

Berdasarkan pengamatan di lapangan, kondisi tapak pada kawasan perencanaan menggunakan bahu jalan sebagai lahan parkir, sehingga mengakibatkan kemacetan di sepanjang jalan. Sistem parkir pada kawasan juga tidak tertata dengan baik. lokasi parkir kendaraan di lokasi Penelitian berada di sepanjang jalan (on street parking) dengan panjang jalan yang menjadi kawasan parkir adalah kurang lebih 1.105 meter, dengan kapasitas parkir kerdaraan sebanyak 442 kendaraan.

\subsection{KARAKTERISTIK PARKIR \\ a. Durasi Parkir}

Tabel.1. Durasi Parkir Kendaraan di Kawasan Sekitar Pasar

\begin{tabular}{|c|c|c|c|c|c|c|c|}
\hline \multicolumn{8}{|c|}{ jl. Yos Sudarso } \\
\hline \multicolumn{3}{|c|}{ Mobil } & \multirow[b]{2}{*}{ 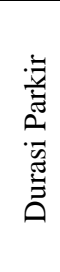 } & \multicolumn{3}{|c|}{ Motor } & \multirow[b]{2}{*}{ 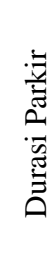 } \\
\hline 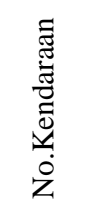 & 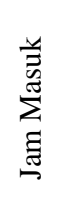 & 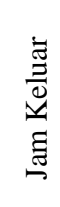 & & 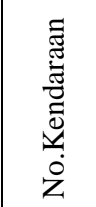 & $\begin{array}{l}\text { 䔍 } \\
\sum_{\bar{J}}^{ \pm} \\
\text {志 }\end{array}$ & 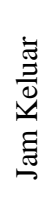 & \\
\hline $\begin{array}{l}\frac{\sigma}{\sigma} \\
\frac{\sigma}{6}\end{array}$ & $\begin{array}{l}\stackrel{\partial}{\circ} \\
\dot{o}\end{array}$ & $\stackrel{=}{\stackrel{0}{0}}$ & $\stackrel{\infty}{\circ}$ & 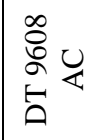 & $\begin{array}{l}\delta \\
\dot{0} \\
\dot{0}\end{array}$ & $\underset{0}{=}$ & oे \\
\hline 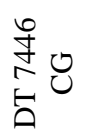 & $\underset{\infty}{=}$ & $\begin{array}{l}\text { तે } \\
\infty \\
\infty\end{array}$ & $\stackrel{?}{\circ}$ & 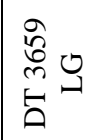 & $\begin{array}{l}\hat{0} \\
\dot{\infty}\end{array}$ & $\underset{\infty}{\stackrel{0}{0}}$ & $\frac{t}{0}$ \\
\hline 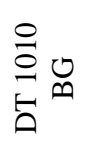 & $\frac{\infty}{\infty}$ & $\begin{array}{l}\bar{m} \\
\ddot{0}\end{array}$ & $\stackrel{m}{0}$ & ن & $\begin{array}{l}a \\
\dot{0} \\
\dot{0}\end{array}$ & $\begin{array}{l}\text { ते } \\
\infty \\
\infty\end{array}$ & $\overline{0}$ \\
\hline \multicolumn{8}{|c|}{ jl. Monginsidi pasar } \\
\hline \multicolumn{3}{|c|}{ Mobil } & & \multicolumn{3}{|c|}{ Motor } & \\
\hline 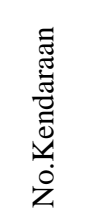 & 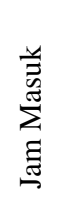 & 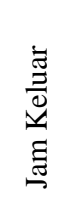 & 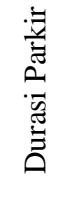 & 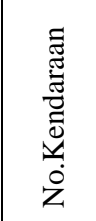 & 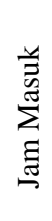 & 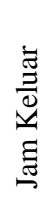 & 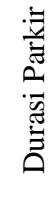 \\
\hline $\begin{array}{l}\tilde{f} \\
\stackrel{f}{6} \\
\stackrel{6}{a}\end{array}$ & $\begin{array}{l}\ddot{0} \\
\dot{8}\end{array}$ & $\frac{7}{8}$ & $\stackrel{0}{0}$ & $\begin{array}{l}\text { ले } \\
\frac{\operatorname{m}}{6} \\
\end{array}$ & $\begin{array}{l}\tilde{O} \\
\dot{g}\end{array}$ & $\frac{ \pm}{g}$ & $=$ \\
\hline 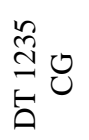 & $\frac{0}{8}$ & $\begin{array}{l}\tilde{a} \\
\stackrel{8}{8}\end{array}$ & $\stackrel{n}{0}$ & 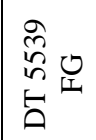 & $\begin{array}{l}\hat{0} \\
\dot{8}\end{array}$ & $\frac{7}{8}$ & $\overrightarrow{0}$ \\
\hline
\end{tabular}




\begin{tabular}{|c|c|c|c|c|c|c|c|}
\hline 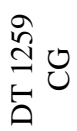 & $\frac{1}{8}$ & $\begin{array}{l}\text { กิ } \\
\text { g }\end{array}$ & $\stackrel{\infty}{\stackrel{0}{0}}$ & 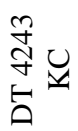 & $\begin{array}{l}\text { đ̦ } \\
\stackrel{8}{8}\end{array}$ & $\begin{array}{l}0 \\
\stackrel{2}{8} \\
\stackrel{8}{2}\end{array}$ & $\stackrel{\sim}{\circ}$ \\
\hline \multicolumn{8}{|c|}{ jl. D.I. Panjaitan } \\
\hline \multicolumn{3}{|c|}{ Mobil } & \multirow[b]{2}{*}{ 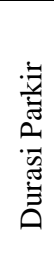 } & \multicolumn{3}{|c|}{ Motor } & \multirow[b]{2}{*}{ 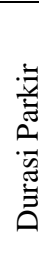 } \\
\hline 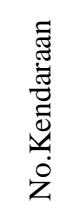 & 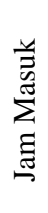 & 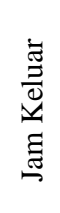 & & 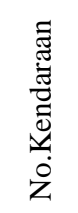 & 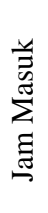 & 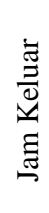 & \\
\hline 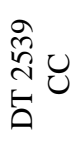 & $\frac{n}{0}$ & $\stackrel{\overbrace{}}{\stackrel{n}{0}}$ & $\stackrel{\infty}{\circ}$ & 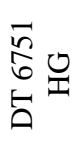 & $\stackrel{a}{\circ}$ & $\stackrel{n}{0}$ & $\begin{array}{l}\text { t. } \\
\stackrel{0}{0}\end{array}$ \\
\hline 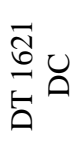 & $\begin{array}{l}\bar{\jmath} \\
\stackrel{0}{\sigma}\end{array}$ & 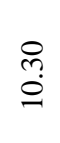 & $\stackrel{\circ}{\circ}$ & $\begin{array}{l}\stackrel{n}{\sim} \\
\stackrel{n}{\omega} \\
x\end{array}$ & $\vec{\Xi}$ & $\stackrel{ \pm}{\stackrel{0}{0}}$ & 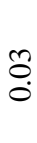 \\
\hline 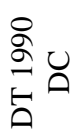 & 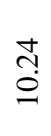 & $\stackrel{m}{\varrho}$ & $\stackrel{\circ}{\circ}$ & 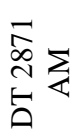 & $\frac{ \pm}{0}$ & $\stackrel{\infty}{0}$ & 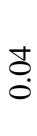 \\
\hline \multicolumn{8}{|c|}{ jl. R.A Kartini ruko } \\
\hline \multicolumn{3}{|c|}{ Mobil } & \multirow[b]{2}{*}{ 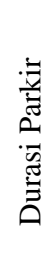 } & \multicolumn{3}{|c|}{ Motor } & \multirow[b]{2}{*}{ 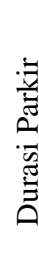 } \\
\hline 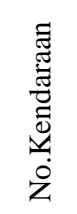 & 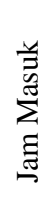 & 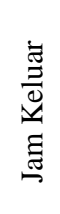 & & 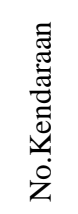 & 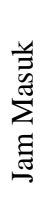 & 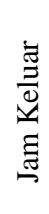 & \\
\hline 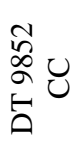 & $\underset{\sigma}{\bar{\sigma}}$ & $\stackrel{\overbrace{}}{=}$ & 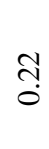 & 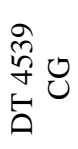 & $\underline{\underline{\sigma}}$ & $\begin{array}{l}= \\
\Xi\end{array}$ & $\stackrel{\text { to }}{\circ}$ \\
\hline 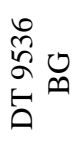 & $\stackrel{ }{\Xi}$ & $\begin{array}{l}\stackrel{9}{=} \\
=\end{array}$ & $\stackrel{1}{\circ}$ & 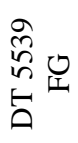 & $\stackrel{8}{\text { ga }}$ & $\stackrel{m}{=}$ & $\stackrel{+}{0}$ \\
\hline 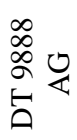 & $\stackrel{\text { กิ }}{=}$ & $\bar{\eta}$ & $=$ & 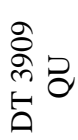 & $\stackrel{m}{=}$ & $\stackrel{\infty}{\beth}$ & ஜே \\
\hline \multicolumn{8}{|c|}{ jl. P. Tendean } \\
\hline \multicolumn{3}{|c|}{ Mobil } & & \multicolumn{3}{|c|}{ Motor } & \\
\hline 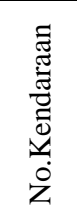 & 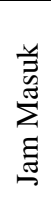 & 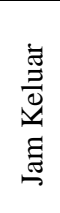 & 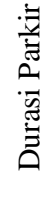 & 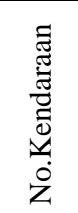 & 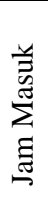 & 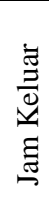 & 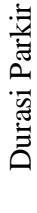 \\
\hline
\end{tabular}

\begin{tabular}{|c|c|c|c|c|c|c|}
\hline 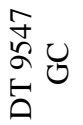 & $\stackrel{\text { f }}{=}$ & ? & $\begin{array}{l}\infty \\
0 \\
0\end{array}$ & $\begin{array}{l}\text { 志 } \\
\text { ปे } \\
\stackrel{\Delta}{\Delta}\end{array}$ & 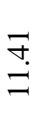 & $\begin{array}{l}\underset{\Xi}{=} \\
\end{array}$ \\
\hline 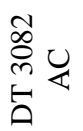 & $\stackrel{n}{\exists}$ & $\begin{array}{l}\text { ñ } \\
\end{array}$ & $\overrightarrow{0}$ & 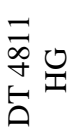 & 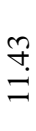 & $\underset{\text { 导 }}{=}$ \\
\hline$\frac{\infty}{\stackrel{\infty}{\sigma}} \underset{n}{\Sigma}$ & n & $\begin{array}{l}\text { ¿ } \\
\text { İ }\end{array}$ & $\tilde{n}$ & 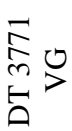 & $\stackrel{\text { f. }}{=}$ & ñ \\
\hline
\end{tabular}

Sumber: Hasil Analisis 2016

Berdasarkan data durasi parkir diatas dapat diketahui Durasi parkir kendaraan pada Kawasan sekitar pasar dan masjid agung berkisar antara 1 menit - 30 menit atau berkisar rata-rata 26,1 menit. Data durasi parkir tersebut didapatkan melalui survei number platematching dengan selisih waktu kendaraan masuk dan waktu kendaraan keluar area parkir.

Tabel.2 : Durasi Parkir Kendaraan di Kawasan UMNA Plaza

\begin{tabular}{|c|c|c|c|c|c|c|c|c|c|c|c|c|}
\hline \multirow{3}{*}{ no } & \multicolumn{12}{|c|}{ BSHLtenkJU } \\
\hline & \multicolumn{3}{|c|}{$v: 1$} & lizi & \multicolumn{3}{|c|}{ wax } & \multirow{2}{*}{ lis } & \multicolumn{3}{|c|}{$\mathrm{bs}$} & \multirow{2}{*}{$\begin{array}{l}\mathrm{Wz} \\
\mathrm{ine}\end{array}$} \\
\hline & Wuluta & $x+1: 21$ & sidx & sw & biown & ballest & and:a & & $k x$ tax & $\int \sin 16 x$ & trk:le & \\
\hline 1 & $r ; y \%$ & $\because 1$ & lis & เ‼ & raxule & US: & $: 123$ & $w \mathbf{r}$ & แ!Lว & 11. & $\mathscr{L X}$ & [2! \\
\hline 2 & $\mathrm{r}: \mathrm{in}$ & 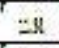 & list & Li & r:wett & $11 \mathrm{i} T$ & $: 12$ & 08 & KESK & 1l: & 13!! & is \\
\hline 3 & 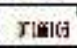 & $=1$ & lie & $\lfloor 3 i$ & Nax:5\%) & $\mathrm{HL}_{\mathrm{i}} \mathrm{T}$ & :155 & $0 \mathrm{~B}$ & 사 $x$ & 11:5 & I3I & 15: \\
\hline
\end{tabular}

Sumber: Hasil Analisis 2016

Berdasarkan data durasi parkir diatas dapat diketahui Durasi parkir kendaraan pada Kawasan Umna Plaza berkisar antara 20 menit - 120 menit (2 jam). Data durasi parkir tersebut didapatkan melalui survei number platematching dengan selisih waktu kendaraan masuk dan waktu kendaraan keluar area parkir.

\section{b. Pergantian Parkir}

\begin{tabular}{|c|c|c|c|c|}
\hline No & WAKTU & $\begin{array}{c}\text { Rata-rata } \\
\text { Volume } \\
\text { parkir } \\
\text { kendaraan } \\
\text { per hari }\end{array}$ & $\begin{array}{c}\text { Kapasitas } \\
\text { Parkir di } \\
\text { Jalan }\end{array}$ & $\begin{array}{c}\text { Parkir } \\
\text { turn } \\
\text { over }\end{array}$ \\
\hline 1 & $06.00-07.00$ & 617 & 442 & 1.396 \\
\hline 2 & $07.01-08.00$ & 846 & 442 & 1.914 \\
\hline 3 & $08.01-09.00$ & 1138 & 442 & 2.575 \\
\hline 4 & $09.01-10.00$ & 1488 & 442 & 3.367 \\
\hline 5 & $10.01-11.00$ & 1844 & 442 & 4.172 \\
\hline 6 & $11.01-12.00$ & 1864 & 442 & 4.217 \\
\hline 7 & $12.01-13.00$ & 1843 & 442 & 4.170 \\
\hline 8 & $13.01-14.00$ & 1903 & 442 & 4.305 \\
\hline 9 & $14.01-15.00$ & 1634 & 442 & 3.697 \\
\hline
\end{tabular}




\begin{tabular}{|c|c|c|c|c|}
10 & $15.01-16.00$ & 1635 & 442 & 3.699 \\
\hline 11 & $16.01-17.00$ & 1361 & 442 & 3.079 \\
\hline 12 & $17.01-18.00$ & 913 & 442 & 2.066 \\
\hline 13 & $18.01-19.00$ & 744 & 442 & 1.683 \\
\hline 14 & $19.01-20.00$ & 629 & 442 & 1.423 \\
\hline
\end{tabular}

Sumber: Hasil Analisis, 2016

Berdasarkan perhitungan diatas didapat turnover parking/pergantian parkir tertinggi adalahpada jam 13.00-14.00 WITA sebesar 4,305 yang menunjukan bahwa pergantian parkir pada jampengamatan sudah melebihi batas normal/nilai turnover parkingtelah melewati angka 1.

c. Indeks Parkir

\begin{tabular}{|c|c|c|c|c|}
\hline No & WAKTU & $\begin{array}{c}\text { Rata-rata } \\
\text { Volume } \\
\text { parkir } \\
\text { kendaraan } \\
\text { per hari }\end{array}$ & $\begin{array}{c}\text { Kapasitas } \\
\text { Parkir di } \\
\text { Jalan }\end{array}$ & $\begin{array}{l}\text { Indeks } \\
\text { Parkir }\end{array}$ \\
\hline 1 & $06.00-07.00$ & 617 & 442 & 1.396 \\
\hline 2 & $07.01-08.00$ & 846 & 442 & 1.914 \\
\hline 3 & $08.01-09.00$ & 1138 & 442 & 2.575 \\
\hline 4 & $09.01-10.00$ & 1488 & 442 & 3.367 \\
\hline 5 & $10.01-11.00$ & 1844 & 442 & 4.172 \\
\hline 6 & $11.01-12.00$ & 1864 & 442 & 4.217 \\
\hline 7 & $12.01-13.00$ & 1843 & 442 & 4.170 \\
\hline 8 & $13.01-14.00$ & 1903 & 442 & 4.305 \\
\hline 9 & $14.01-15.00$ & 1634 & 442 & 3.697 \\
\hline 10 & $15.01-16.00$ & 1635 & 442 & 3.699 \\
\hline 11 & $16.01-17.00$ & 1361 & 442 & 3.079 \\
\hline 12 & $17.01-18.00$ & 913 & 442 & 2.066 \\
\hline 13 & $18.01-19.00$ & 744 & 442 & 1.683 \\
\hline 14 & $19.01-20.00$ & 629 & 442 & 1.423 \\
\hline
\end{tabular}

\section{Sumber: Hasil Analisis, 2016}

Besarnya indeks parkir tertinggi diperoleh dari perbandingan antara akumulasi parkir denganruang parkir yang tersedia. Indeks parkir tertinggi adalah pada jam 13.00 - 14.00 WIBsebesar 4,305. Rata-rata Nilai indeks parkir pada Kawasan perencanaan< 1 menunjukkan bahwa fasilitasparkir di jalan yang telah tersedia sudah tidak mampu menampung kebutuhan parkir kendaraan/melebihi kapasitas normal. Sehingga di butuhkan perencanaan pembangunan fasilitas parkir kendaraan di Kawasan sekitar Pasar dan Masjid Agung.

\section{d. Kebutuhan Parkir}

\begin{tabular}{|c|c|c|c|c|c|c|}
\hline$z^{\circ}$ & $\begin{array}{l}? \\
\frac{1}{3} \\
3\end{array}$ & 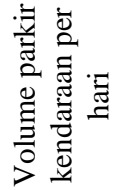 & 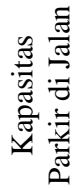 & 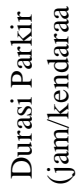 & 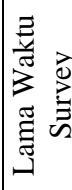 & 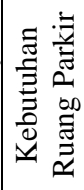 \\
\hline
\end{tabular}

\begin{tabular}{|c|c|c|c|c|c|}
\hline 1 & $06.00-07.00$ & 617 & 442 & \multirow{14}{*}{0.44} & \multirow{15}{*}{14} \\
\hline 2 & $07.01-08.00$ & 846 & 442 & & \\
\hline 3 & $08.01-09.00$ & 1138 & 442 & & \\
\hline 4 & $09.01-10.00$ & 1488 & 442 & & \\
\hline 5 & $10.01-11.00$ & 1844 & 442 & & \\
\hline 6 & $11.01-12.00$ & 1864 & 442 & & \\
\hline 7 & $12.01-13.00$ & 1843 & 442 & & \\
\hline 8 & $13.01-14.00$ & 1903 & 442 & & \\
\hline 9 & $14.01-15.00$ & 1634 & 442 & & \\
\hline 10 & $15.01-16.00$ & 1635 & 442 & & \\
\hline 11 & $16.01-17.00$ & 1361 & 442 & & \\
\hline 12 & $17.01-18.00$ & 913 & 442 & & \\
\hline 13 & $18.01-19.00$ & 744 & 442 & & \\
\hline 14 & $19.01-20.00$ & 629 & 442 & & \\
\hline To & & 18459 & & & \\
\hline
\end{tabular}

Sumber: Hasil Analisis 2016

Dari hasil perhitungan diatas dapat diketahui jumlah kebutuhan ruang parkir berdasarkanhasil perhitungan jumlah kendaraan selama pengamatan yaitu sebesar 580 SRP. sedangkan kapasitas parkir di jalan adalah sebesar 442 SRP,hal tersebut menunjukan bahwa kebutuhan ruang parkir berdasarkan hasil perhitungan pengamatan lapangan sudah tidak memenuhi kapasitas parkir kendaraan di jalan.

\section{KESIMPULAN}

Konsep dan karakteristik parkir, analisis kebutuhan parkir, perencanaan geometrik lahan parkir, serta kebijakan parkir merupakan salah satu ide yang bias diimplementasikan untuk menangani permasalahan parkir khususnya di Kota Baubau. Saat ini perparkiran menjadi salah satu fenomena yang mempengaruhi pergerakan kendaraan disaat kendaraan-kendaraan yang mempunyai intensitas pergerakan yang begitu tinggi akan terhambat oleh kendaraan yang parkir di bahu jalan sehingga menyebabkan kemacetan.

Pada umumnya kendaraan yang parkir di pinggir jalan berada di sekitar tempat atau pusat kegiatan seperti : sekolah, kantor, pasar swalayan, pasar tradisional, rumah makan, dan lain-lain. Salah satu usaha yang perlu dilakukan untuk menangani masalah perparkiran tersebut, diperlukan pengadaan lahan parkir yang cukup memadai dan pembentukan model lahan parkir yang tepat pada lahan parkir yang tersedia, mengingat kebutuhan akan lahan parkir (demand) dan prasarana yang dibutuhkan (supply) harus seimbang dengan karakteristik perparkiran.

Parkir semestinya hanya digunakan untuk memberhentikan kendaraan untuk sementara, tidak dalam waktu lama atau bahkan berhari-hari yang dilakukan. Penggunaan parkir sesuai peraturan yang 
rapi akan memudahkan petugas parkir dalam memarkirkan kendaraan.

\section{DAFTAR PUSTAKA}

- Peraturan Pemerintah Nomor 27 Tahun 1999 Tentang Analisis Mengenai Dampak Lingkungan (Lembaran Negara Tahun 1999 Nomor 59, Tambahan Lembaran Negara Nomor 3838);

- Peraturan Menteri Perhubungan Nomor KM 35 Tahun 2003 tentang Penyelenggaraan Angkutan Orang di Jalan Dengan Kendaraan Umum;

- Peraturan Menteri Perhubungan Nomor KM 14 Tahun 2006 tentang Manajemen dan Rekayasa Lalu Lintas di Jalan;

- Peraturan Pemerintah Nomor 43 Tahun 1993 tentang Prasarana dan Lalu Lintas Jalan (Lembaran Negara Tahun 1993 Nomor 63, Tambahan Lembaran Negara Nomor 3529);

- Rencana Tata Ruang Wilayah Provinsi Sulawesi Tenggara

- Rencana Tata Ruang Wilayah Kota Baubau

- Standar kebutuhan petak parker, Direktorat Jenderal Perhubungan Darat RI, Departemen Perhubungan

- Tataran Transportasi Lokal Kota Baubau

- Undang-undang Nomor 14 Tahun 1992 tentang Lalu Lintas dan Angkutan Jalan (Lembaran Negara Tahun 1992 Nomor 49, Tambahan Lembaran Negara Nomor 3480);

- Undang-Undang Nomor 23 Tahun 1997 Tentang Pengelolaan Lingkungan Hidup (Lembaran Negara Tahun 1997 Nomor 68, Tambahan Lembaran Negara Nomor 3699);

- Undang-undang Nomor 38 Tahun 2004 tentang Jalan (Lembaran Negara Tahun 2004 Nomor 132, Tambahan Lembaran Negara Nomor 4444);

- Undang-undang Nomor 26 Tahun 2007 tentang Penataan Ruang; 